\title{
The fungus, the Code and the mysterious publication date: Why Gnomoniopsis smithogilvyi is still the correct name for the chestnut rot fungus
}

This letter is a response to the ongoing confusion regarding the name to be used for the chestnut rot pathogen, Gnomoniopsis smithogilvyi (Gnomoniaceae, Diaporthales). The first author recently received correspondence from Australia that academics and industry believe there are two fungal species that are the main agents causing chestnut rot. There is only one main causal agent of chestnut rot in Australia, New Zealand, and Europe, and its correct name is G. smithogilvyi. Here we explain why.

In 2012, two groups independently described a fungus from Castanea spp. causing chestnut rot. The first, Gnomoniopsis smithogilvyi, was effectively published online on 4 June 2012 in Persoonia with the publication date given on it (Crous et al. 2012). The second, originally named Gnomoniopsis 'castanea' (Visentin et al. 2012), has no publication date written on the fulltext PDF, but was found to have been published on 21 July 2012 (Shuttleworth et al. 2015). This publication date can be verified via a Web of Science search as it is not observable on the Journal of Plant Pathology (JPP) website (Visentin et al. 2012).

In 2015, a paper was published showing the two names represent the same species, with $G$. smithogilvyi having priority due to the earlier effective publication date (Shuttleworth et al. 2015). During the review process of that paper, the exact publication date of $G$. 'castanea' was difficult to ascertain by an independant reviewer who then contacted the editor of JPP, Luisa Rubino. She stated that from the JPP database, the Visentin et al. (2012) article could not have been published before 21 July 2012. Therefore, this was taken as the effective publication date.

In 2016, a letter to the editor was published in JPP citing another personal communication from Luisa Rubino stating that the publication date of $G$. 'castanea' (now being referred to as $G$. 'castaneae' after Shuttleworth et al. 2015 had corrected the Latin), had mysteriously changed to 21 May 2012 and with a DOI (Tamietti 2016). There is no proof of this publication date or of a DOI on the pages of the Visentin et al. (2012) fulltext PDF. After publication of Shuttleworth et al. (2015), a DOI hyperlink and fulltext PDF was added to the JPP website which was not present before 2015 (Shuttleworth 2013). Additionally, Article 30.2 of the Code states that 'An electronic publication is not effectively published if there is evidence within or associated with the publication that its content is merely preliminary and was, or is to be, replaced by content that the publisher considers final, in which case only the version with that final content is effectively published' (Turland et al. 2018).

There is evidence from 13 June 2012 that the Visentin et al. (2012) article was then only available from the JPP website as an Abstract (Shuttleworth 2013). There is also evidence on the Visentin et al. (2012) fulltext PDF that the article was received on 10 April 2012, and accepted on 4 May 2012. However, neither of these dates is one of an effective publication; the effective publication date of $G$. 'castaneal castaneae' is the date when the final version of the paper was available online, which was July 2012, and most likely 21 July 2012.

Unfortunately, what appears to be a campaign to use the later incorrect name has emerged (Lione et al. 2018, Gonthier et al. 2017, Sillo et al. 2017, Tamietti 2016), attempting to discredit Shuttleworth et al. (2015) and Mycotaxon, the publisher of the article (Gonthier $e t$ al. 2017).

This raises important questions in regard to the wilful refusal of scientists to observe the rules of the Code. Articles using the incorrect name continue to appear, and one author who previously used the correct name switched to using the incorrect name (Lione et al. 2018, Pasche et al. 2016).

In cases of nomenclatural uncertainty, it is possible for the relevant permanent committee, which in this case would be the Nomenclature Committee for Fungi (NCF) to be asked for a binding decision via a published request in Taxon. We do not, however, consider this necessary as there is no evidence that the name
$G$. castaneae was actually effectively published before G. smithogilvyi.

There is only one main causal agent of chestnut rot in Australia, New Zealand, and Europe, and its correct name is Gnomoniopsis smithogilvyi.

\section{REFERENCES}

Crous PW, Summerell BA, Shivas RG, Burgess TI, Decock CA, et al. (2012) Fungal Planet Description Sheets: 107-127. Persoonia 28: 138-182.

Gonthier P, Visentin I, Valentino D, Tamietti G (2017) The legitimate name of a fungal plant pathogen and the ethics of publication in the era of traceability. Science and Engineering Ethics 23: 631.

Lione G, Danti R, Fernandez-Conradi P, FerreiraCardoso JV, Lefort F, et al. (2018) The emerging pathogen of chestnut Gnomoniopsis castaneae: the challenge posed by a versatile fungus. European Journal of Plant Pathology. Published online 31 Aug 2018. https://doi.org/10.1007/ s10658-018-1597-2

Pasche S, Calmin G, Auderset G, Crovadore J, Pelleteret P, et al. (2016) Gnomoniopsis smithogilvyi causes chestnut canker symptoms in Castanea sativa shoots in Switzerland. Fungal Genetics and Biology 87: 9-21.

Shuttleworth LA (2013) The biology and management of chestnut rot in south-eastern Australia. PhD thesis, University of Sydney, Australia. http://hdl.handle.net/2123/10082

Shuttleworth LA, Walker DM, Guest DI (2015) The chestnut pathogen Gnomoniopsis smithogilvyi (Gnomoniaceae, Diaporthales) and its synonyms. Mycotaxon 130: 929-940.

Tamietti G (2016) On the fungal species Gnomoniopsis castaneae ('castanea') and its synonym G. smithogilvyi. Journal of Plant Pathology 98: 189-190.

Turland NJ, Wiersema JH, Barrie FR, Greuter W, Hawksworth D L, et al. (eds) (2018) International Code of Nomenclature for algae, fungi, and plants (Shenzhen Code) adopted by the Nineteenth International Botanical Congress Shenzhen, China, July 2017. 
[Regnum Vegetabile no. 159.] Glashütten: Koeltz Botanical Books.

Visentin I, Gentile S, Valentino D, Gonthier P, Tamietti G, Cardinale F (2012) Gnomoniopsis castanea sp. nov. (Gnomoniaceae, Diaporthales) as the causal agent of nut rot in sweet chestnut. Journal of Plant Pathology 94: 411-419.

\section{Lucas A. Shuttleworth ${ }^{1}$, David I. Guest ${ }^{1}$,} and Donald M. Walker ${ }^{2}$

${ }^{1}$ University of Sydney, Sydney School of Agriculture, Australian Technology Park, Eveleigh, NSW 2015, Australia (lucasashuttleworth@gmail.com) ${ }^{2}$ Middle Tennessee State University, Toxicology and Disease Group, Biology Department, PO Box 60, Murfreesboro,

TN 37132, USA 